\title{
Broaden and build theory of pain association
}

\author{
Shubham Sharma ${ }^{1 *}$, Akshyata Ray $^{2}$, Dr. Mnayitre Ghoshal ${ }^{3}$
}

\section{ABSTRACT}

Why do we relate to pain so much in our life? Is it a bad thing to experience pain in life or is it a blessing? Many people might have varied perspective of pain but majority always views pain as a negative thing in life but on searching and asking about what exactly pain is the results found that pain actually is just an environment which our body mind and brain together creates for us. We create pain in ourselves in order to grow and evolve.

Keywords: Pain Association, Broaden and Build, Growth, Evolution.

Since a long time, theories of well-being and positivity have been the focus of psychologists. No doubt there are numerous benefits of positivity and well-being, and it has it place in the growth and development of the person. But when we talk about mundane scenarios, usually it has been observed that contentment hampers development in the everyday setting. Whereas our association with pain and our dissatisfaction is the motivating factor. For instance, we take a job setting and study the cases of two individuals. Individual A is satisfied with his work place, it may not be his ideal place but he has inculcated the philosophy of being content with whatever he has and has created a comfort zone within that arena. Individual A wouldn't strive hard to change his work setting and hence is not opening himself to the wide arena of opportunities lying in front of him. Similarly, there is an Individual B who is not satisfied with his work place and has this deep-rooted philosophy that putting ourselves through pain and turmoil would result in a better life later. The anticipation for a better future would result in that individual to transform his life and open a wide ocean of opportunities for him.

The evolutionary concept of emotions prove that negative emotions like rage, fear, etc are needed for the purpose of survival and evolution (Darwin, 1859). Keeping in mind the necessity of negative emotions, pain can be viewed as an essential aspect from the perspective of survival and evolution. But when we talk about pain, the thought of experiencing pain cringes us and instills a sense of fear in us. From a biological perspective, pain asks for attention and insidiously clasps all aspect of a person's life. Also, it has been found that pain urges an individual to move towards protection, it is considered as a

${ }^{1}$ Doon University, Dehradun, India

${ }^{2}$ Doon University, Dehradun, India

${ }^{3}$ Doon University, Dehradun, India

*Responding Author

Received: April 6, 2020; Revision Received: May 15, 2020; Accepted: June 25, 2020

(C) 2020, S Sharma, A Ray \& M Ghoshal; licensee IJIP. This is an Open Access Research distributed under the terms of the Creative Commons Attribution License (www.creativecommons.org/licenses/by/2.0), which permits unrestricted use, distribution, and reproduction in any Medium, provided the original work is properly cited. 
propeller towards protective behavior (Moseley, 2015). Pain when transcends the level of chronic pain, makes the individual feel helpless. Broaden and build theory of positive emotions (Fredrickson, 2004) states that positive emotions are essential for growth, development and broadening of perspective of an individual.

\section{Pain}

The definition of pain as stated by the International Association for the Study of Pain is "an unpleasant sensory and emotional experience associated with actual or potential tissue damage, or described in terms of such damage". Biologists regard pain as a reaction to biological damage. Also, pain in general is a subjective concept. No matter what a person's threshold for experiencing pain maybe and irrespective of the fact that where the pain is being felt, it is an unpleasant sensation and hence is deemed as a negative emotion. Pain broadly has two dimensions- sensory dimension and cognitive dimension. The sensory dimension of pain states the part where the pain is felt and cognitive dimension refers to how an individual interprets pain based on his past experience (Crofford, 2015). Pain in this research paper talks about the cognitive dimension of pain.

\section{Broaden and build theory of positive emotions}

Broaden and build theory of positive emotions (Fredrickson, 2004) enlists the essentiality of positive emotions in our life. The main postulates of the theory states that positive emotions i) broaden our thinking and attention, ii) reduce the effect of negative emotions, iii) build psychological resilience, iv) add our personal resources, v) promote well-being, and vi) result in development of an individual. The theory in details enlists the importance of cultivating positive emotions in an individual.

\section{Significance of the study}

Why do individuals feel pain in their life and what is the root cause of it. If we try to see and understand the core root of pain we would understand that the primary reason which causes pain is the unfulfillment of desires in our life. The source and reasons for experiencing pain can be different but when the desire is not fulfilled in our life due to one or other reasons, we feel pain. Since many centuries, pain as been associated only as a negative feeling, but this research aims to change our perspective how we want to view pain. The research explains pain association as a broaden and build concept along with substantiating the text with concepts like resilience and post traumatic growth.

\section{Aims/Objectives}

To present the broaden and build theory of pain association.

\section{Source of population and selection criteria}

The population considered for this research fell in the age group of 18-25 and belonged to India. The subjects were selected on their notion of pain, i.e. they viewed pain as a negative thing.

\section{Participants}

Total 50 subjects participated in the research. Gender was not a parameter.

\section{Tools and techniques}

Self structured questionnaire consisting of 6 open questions. 50 people were given a written interview. First a consent form was given to them, after which they were given 6 open questions to answer. The results stated that all 50 participants before the interview viewed 
pain in a negative aspect but then they were asked to change their perception of pain and view it in a positive connotation and again interviewed via the self structure questionnaire, 35 of them felt good and more motivated after feeling pain. 10 said that they viewed pain in a positive light now but they found it difficult to implement it and wanted time to do it. The rest 5 were confused.

The main reason of cognitive dimension of pain is the unfulfillment of underlying desires. Some primary reasons for prevalence of cognitive dimension of pain in subjects were found to be due to loosing someone whom we deemed as fulfilling them, some traumatic event that happened which took some good things or memories from them which made them unfulfilled, loosing self worth, not achieving what they wanted, etc.

We are organisms which keep on evolving since the onset of existence but what motivates us for evolving is pain. Pain develops us, it does everything emotionally, hormonally and somatically to grow and evolve from that situation. This is because nothing is the end in this world and there is always a cycle creation and destruction. But why is it so that when we are happy, satisfied in our life, we see pain as the true question. While interviewing subjects and understanding what they felt about pain, most of the people gave similar types of answers. Some answers to the question "What is pain in emotional sense", are as follows:

1. When you get detached or separate from yourself that's pain.

2. Pain in my words is some incomplete thing which is left in your life; which never be completed. Regret is also a pain.

When further asked to explain pain, 40 subjects stated they all felt unfulfillment of one or another thing in their life is pain. While experiencing pain, hormones are released which helps us fight the situation and hence our views should change about pain. The concept of resilience and post traumatic growth work in favor of pain and gives us a better perception of life including appreciation towards life. Based on the data obtained, it was found that some other long-term benefits of pain are improved emotional intelligence-in inter relationships, give new possibilities in life, increases personal strength for fighting any situation and also result in spiritual change.

In the theory death drive (Freud, 1987) explains that people experience a drive of selfdestruction. As a need to feel alive, some people move towards dangerous activities like reckless driving or going for extreme sports to feel the thrills, and this is explained as death drive by Sigmund Freud. If we closely see what exactly comes out from this theory, it states that if one tries everything to come out of their present realities which causes pain then they grow. In reality, they are not understanding reason why they are feeling pain, it is not there to make them suffer but to make them realize that it is time to move on and grow positively.

Similarly, the concept of resilience and post traumatic growth support the broaden and build concept of pain. Resilience is defined as the ability to resist a negative event and post traumatic growth is defined as development or bouncing back after a traumatic event. Both these concepts was understood by the concept of PTSD (Yehuda et al., 2013). The people who didn't show the effect of PTSD after a major event were classified into two groups. One group was found to be unaffected by the effects of PTSD and this group showed the property of resilience. Similarly, the other group felt the effects of PTSD, but soon emerged victorious and grew out of it. Their property was termed as post traumatic growth (Southwick, 2014). Both these properties show the broaden and build concept of negative emotions. 


\section{CONCLUSION}

It is found that people who are accomplished, happy and satisfied in life also feel the pain of unfulfillment. The reason why they feel so, it's core, is to grow and evolve. Further, whenever a person's life is stuck in something, which is hindering his evolution and growth as an individual, pain emerges. Pain is not just mere experiencing phenomena but it is a red flag for the body, mind, brain, emotions and tells us to understand ourselves and don't feel down with our pain but evolve from it.

Pain is not a bad thing and the illusion that we carry for the word pain has to change. Everything good happens within us and similarly when we suffer and experience pain, it signifies that we want to grow in life, understand ourselves and we become more positive about life. We have to understand pain is a positive sign stating that we want to grow.

\section{REFERENCES}

Crofford L. J. (2015). Chronic Pain: Where the Body Meets the Brain. Transactions of the American Clinical and Climatological Association, 126, 167-183.

Darwin, C. (1859) Origin of Species.

Fredrickson B.L. (2004). The broaden-and-build theory of positive emotions. The Royal Society, 1367-1377.

Freud S. (1987), "Beyond the Pleasure Principle" in On Metapsychology, 316.

Merskey H, Bogduk N. Classification of Chronic Pain: Descriptions of Chronic Pain Syndromes and Definitions of Pain Terms, 2nd Edition. Seattle, Washington: International Association for the Study of Pain (IASP) Press; 1994.

Moseley G.L., Butler D.S. Fifteen years of explaining pain: the past, present, and future. $J$ Pain. 2015;16:807-813.

Southwick S.M. et al. (2014). Resilience definitions, theory, and challenges: interdisciplinary perspectives. European Journal of Psychotraumatology, 5, 2014 Issue 1.

Yehuda R., Daskalakis N. P., Desarnaud F., Makotkine I., Lehrner A. L., Koch E. Epigenetic biomarkers as predictors and correlates of symptom improvement following psychotherapy in combat veterans with PTSD. Frontiers in Psychiatry. 2013; 4: 118 .

\section{Acknowledgements}

The author appreciates all those who participated in the study and helped to facilitate the research process.

\section{Conflict of Interest}

The author declared no conflict of interest.

How to cite this article: S Sharma, A Ray \& M Ghoshal (2020). Broaden and build theory of pain association. International Journal of Indian Psychology, 8(2), 122-125. DIP:18.01.015/20200802, DOI:10.25215/0802.015 